\title{
ЯПОНЫ ТОГТВОРТОЙ АЯЛАЛ ЖУУЛЧЛАЛЫН БОДЛОГО БА ЭКОТУРИЗМ
}

\section{Б.Саранчимэг}

Орчин үед дэлхий дахины хөгжслий ерөнхий чиг хандлага нь зохистой хэрэглээг төлөвщүүлэх, байгаль орчинд ээлтэй үйлдвэрлэлийг бий болгох, улс орнууд өөр өөрийн өвөрмөи шинж төрх, баялгаа хадгалах замаар "ногоон” хэв загварт шилжсиж байна. Ийм нөхиөлд дэлхийн улс орнуудын эдийн засгийн тулгуур салбарын нэг болж, асар хурдацтай хөгжиж буй аялал жуулчлалын салбарт эерэг, сөрөг нөлөөлөл ихээхэн гарсан байна. Аялал жуулчлальнн үйл ажсиллагаанд хамгийн ихээр өртөгдөж, үндсэн шинж чанараа алдаж байдаг зүйлсүҮд нь байгаль орчин, хүн ардын соёл, уламжлалт зан заншил буюу тухайн улс Үндэстний бусад улс үндэстнээс ялгарах илэрхийлэл болдог Yнэт зүйлс юм. Ногоон хөгжлийн загварыг салбар бүртээ үр дүнтэй хэрэгжүүлж буй Япон орны аялал жуулчлальнн салбарыг судлах нь тогтвортой хөгжлийн зарчмаар алхаж буй Монгол орньл хувьд "Өнөөдрийн жуулчдын харж, мэдэрч буй зүйлийг, маргаашийн жуулчид тэр л байдлаар нь харж мэдрэх ёстой” гэсэн товч бөгөөд тодорхой зарчим биелэлээ олоход жаахан ч гэсэн тус нэмэр болох болов уу.

Түлхүур үгс: Ногоон хөгжил, тогтвортой хөгжил, тогтвортой аялал жуулчлал, экотуризм

Өнөөдөр дэлхий нийтэд аялал жуулчлалыг “Ард түмнҮҮдийн найрамдал, хамтын ажиллагааг идэвхижүүлэгч”, “Утаагүй үйлдвэрлэл”, “Үл Үзэгдэгч экспорт” гэдэг сонгодог утгаар нь 
эрчимтэй хөгжүүлж байна.

Япон улсын тогтвортой аялал жуулчлалын гол бодлого нь Экотуризмыг дэмжин ажиллах бодлого бөгөөд энэ бодлогын дагуу эдийн засгийн өсөлт, байгаль хамгаалах гэсэн 2 зорилгыг хамтад нь хэрэгжүүлэх чиглэлийг мөрдөж иржээ.

Өнгөрсөн зуунд Япон улс аялал жуулчлалын салбараар дамжуулан эдийн засгаа өсгөх оновчтой стратеги боловсруулсан. 1963 онд Аялал жуулчлалын үндсэн хуулийг бүхэлд нь шинэчилж, "Үндэсний аялал жуулчлалыг хөгжүүлэх суурь хууль" -ийг баталснаар, Японы Засгийн газар аялал жуулчлалын салбарыг XXI зууны улс төрийн тулгуур бодлогын нэг гэж тодорхойлсон. Тус хуулийн заалтыг үндэслэн 2012 оны 3 дугаар сарын 30-нд "Үндэсний аялал жуулчлалыг хөгжүүлэх суурь төлөвлөгөөг" боловсруулж, засгийн газраар батлуулсан. Японд жил бүр хэвлэгдэн гардаг “Аялал жуулчлалын цагаан ном"з-д аялал жуулчлалын бодлогын чиг хандлага бүх талын судалгаa, шинжилгээний статистик мэдээг нийтэлж иржээ. ТэрхүҮ статистик мэдээнд тулгуурлан стратеги төлөвлөгөөндөө хүрэх шинэ зорилтыг дэвшүүлж хэрэгжүүлдэг байна.

2013 онд Японыг зорьсон жуулчдын тоо анх удаа 10 сая давсан. Улмаар 2014 онд 13 сая 410 мянга гаруй жуулчин аялжээ.. Япон руу жуулчлах жуулчдын ихэнх хувийг Азийн орнуудаас, тэр дундаа Хятадын жуулчид эзэлж байна. Хятад жуулчдын ихэнх нь Японы сайн чанарын бараа бүтээгдэхүүн, ялангуяа гэр ахуйн цахилгаан барааг их хэмжээгээр худалдан авах зорилготойгоор жуулчилж байна. Үүнээс үүдэж сүүлийн үед аялал жуулчлалын салбарт Inbound consumption гэх нэр томъёо шинээр хэрэглэгдэх боллоо. Энэ нь гадаадын жуулчид японы үндэсний үйлдвэрлэлийн бараа бүтээгдэхүүнийг худалдан авах явдал улам идэвхижиж байгааг заасан нэр томъёо юм. 2014 онд анх удаа Японы эдийн засаг 2 их наяд хүрсэн нь аялал жуулчлалыг эдийн засгийн тэргүүлэх салбар болгон, Inbound consumption-ийг өргөжүүлэхийн тулд аялал жуулчлалтай

\footnotetext{
Үндэсний аялал жуулчлалыг хөгжүүлэх суурь хууль『観光立国推進基本法』

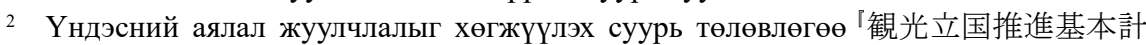
画』

3 Аялал жуулчлалын цагаан ном. 2016 он. Аялал жуулчалын агентлаг. 『観光白書」 平成27年版. 観光庁編

4 Мөн тэнд 4 дүгээр тал.
} 
холбоотой үйлдвэрлэлийг дэмжиж, бүх салбарт жуулчдыг татах үйлчилгээг зохион байгуулж эхэлсэнтэй холбоотой юм. Зөвхөн нэг жишээ дурдахад аль үндэстний жуулчид их зорчиж байгаагаас шалтгаалан тухайн жуулчдын онцлогт тохируулан үйлчилж, тэр хэлээр их харилцах зэрэг менежментийг өргөн ашигладаг байна.

2020 онд Токиод зуны олимп зохион байгуулагдахтай холбогдон Inbound consumption-ийн эрч энэ хэвээрээ байх төлөвтэй байна. Энэ үйл явц өргөжиж буй хүчин зүйл нь Японы бараа бүтээгдэхүүний чанарт итгэх итгэл, иэний ханшийн бууралт, татваргүй бараа зэрэг юм.

2014 оны 6 дугаар сард Үндэсний Аялал Жуулчлалыг Дэмжих Сайд нарын Зөвлөлгөөнөөр 2020 он гэхэд Японд ирэх гадаадын жуулчдын тоог 20 саяд хүргэх зорилтыг хэлэлцсэн. 2015 оны 6 дугаар сард тус хурлаар “20 сая жуулчин”-г угтаж авахад бэлтгэл хийж зам тээврийн байгууламж болон зочид буудлын барилга байгууламжийн хангамжийг сайжруулах талаар хэлэлцэж хүрээлэн буй орчныг засварлахад дорвитой арга хэмжээг авч байна.

Японд ирэх жуулчдын тоо эрс нэмэгдэж буй шалтгаан нь визний нөхцөл зөөлөрсөн, гадаадын жуулчид японы үндэсний бараа бүтээгдэхүүнээс худалдан авалтаас татварын хөнгөлөлт эдэлдэг, бараа бүтээгдэхүүний хямдрал, иэний ханшийн уналт зэрэг хууль эрх зүйн хүчин зүйл ихээхэн нөлөөлж байгаатай холбоотой. Японы аялал жуулчлал олон улсад өрсөлдөх чадвараараа 141 орноос 9-т, Азид 1-т орж, эрүүл ахуй, аюулгүй байдал, өвөрмөц соёлын нөөцтэй, бизнесийн аялал жуулчлал хийхэд хамгийн тохиромжтой гэдгээрээ ийнхүҮ дээгүүр жагсчээ 5 .

Ингэж эдийн засгийн өсөлтийг бий болгож, экологийн тэнцвэрт байдлыг хадгалах замаар тогтвортой аялал жуулчлалын бодлогоо идэвхитэй хэрэгжүүлж байна.

Японд Тогтвортой аялал жуулчлалыг хөгжүүлэхдээ ялангуяа биологийн олон янз байдлыг харгалзан үзэж, аялал жуулчлал, байгаль хамгаалал, нөөцийн тогтвортой ашиглалттай холбоотой олон талын бодлогыг боловсруулдаг байна. Тогтвортой аялал жуулчлалын стратеги төлөвлөгөөнд "Байгаль орчны суурь төлөвлөгөө",

World Economic Forum. The Travel \&Tourism Competitiveness Report 2015.

6 Байгаль орчны суурь төлөвлөгөө, 2000 оны 12 дугаар сар. 『環境基本計画』平成 1 
“Биологийн олон янз байдлын стратеги төлөвлөгөө”, “Ой болон ойн аж ахуйн суурь төлөвлөгөө”, “Далайн эргийг хамгаалах менежмент 7 жилийн хөтөлбөр"9 зэрэг хөтөлбөрүүд хэрэгжиж байна.

Японы Байгаль Орчны Яам (БОЯ) -наас тогтвортой аялал жуулчлалыг дэмжих хэд хэдэн бодлогыг баримталж байгаагаас, нэгд, японд экотуризмыг бий болгох, түүнийг хөгжүүлэх, хоёрт, байгалийн цогцолборт газруудыг зүй зохистой ашиглахад чиглэсэн олон талын төслүүдийг хэрэгжүүлэх, гуравт, БОЯ нь Олон улсын байгаль орчныг хамгаалах холбоо /IUCN/ -ноос боловсруулсан тогтвортой аялал жуулчлалын гарын авлагын зарчмыг түгээх үйл ажиллагаандаa мөрдлөг болгох зэргийг дурьдаж болно. ${ }^{10}$ Эдгээр бодлогын заримаас товч танилцуулбал,

\section{Нэг. Японд эко-аялал жжуулчлальг бий болгох, түҮнийг хөгэжүүлэх Үндсэн чиглэл}

Эко аяллыг дэмждэг гол байгууллагууд Японы Экотуризмын Нийгэмлэг /JES/, Ириомото Екотуризмын Холбоо /IEA/, Халим Ажиглах Холбоо /WWA/зэрэг юм.

2003 оны 11 дүгээр сард Байгаль Орчны Яамны сайд Юрико Коикэ-ийн үед байгаль хамгаaлах, байгалийн нөөц баялгийг зүй зохистой ашиглах, түүх, соёлыг хадгалан хамгаалах зорилготойгоор “Экотуризмыг хөгжүүлэх хороо” байгуулагджээ. Тус хороо нь Газар, Дэд бүтэц, Зам тээврийн яам, ХАА, Ой, Загасны аж ахуйн яам, аялал жуулчлалын агентлагууд болон орон нутгийн засаг захиргааны төлөөлөгчид, мэргэжилтнүүдээс бүрддэг. “Экотуризмыг хөгжүүлэх хороо"-ны үйл ажиллагаа нь эко аяллаар хязгаарлагдахгүй,

\section{2 年 12 月}

7 Япон улсын Биологийн олон янз байдлын стратеги 2012-2020『生物多様性国家前 略2012-2020の構成』

8 Ой болон ойн аж ахуйн суурь төлөвлөгөө, 2016 оны 5 дугаар сар.『森林・林業基 本計画』平成 28 年 5 月

9 "Seven-year Program for Coastal Protection and Management" Japan's sustainable development agenda

10 Best Practices of Sustainable Tourism in JAPAN Submitted to the Ministerial Consultations of the 9th Special Session of the Governing Council / Global Ministerial Environment Forum 
“Үзэсгэлэнт байгальд хэрхэн аялах", “Тусгай хамгаалалттай газарт хэрхэн аялах", түүнчлэн “Байгаль хамгааллын үйл ажиллагаа", “Аж ахуй эрхлэгчдэд зориулсан байгаль хамгаалал” зэрэг байгаль хамгаалах талаар олон нийтэд гүнзгий мэдээлэл түгээх үйл ажиллагааг явуулж иржээ.

Экотуризмыг дэмжсэнээр зөвхөн байгаль хамгаалаад зогсохгүй бүс нутгийн хөгжлийг дэмжихэд ихээхэн хувь нэмэр оруулах талыг энэ арга хэмжээнд чухалчилсан байна. Тогтвортой аялал жуулчлалын гол бодлого нь экотуризм учраас түүний тодорхойлолт, үүсэл хөгжлийг товч дурдах нь зүйтэй болов уу.

Экотуризм нь байгаль орчин сүйтэж эхэлсэн цагаас үүссэн цаг хугацааны бүтээгдэхүүн юм. Олон улсад НҮБ-ын хүрээлэн буй орчны асуудлаар хийсэн анхдугаар бага хурал /Стокгольм, 1972 он/ түүнээс гаргасан тунхагаас эхтэй гэж үздэг. 1982 онд Байгалийн цогцолборт газрын дэлхийн чуулга уулзалтан дээр Олон Улсын Байгаль Хамгаалах Холбооноос /IUCN/ экотуризмыг тодорхойлохдоо “Экотуризмыг байгаль хамгаалахад хөрөнгө босгох чухал арга хэрэгсэл юм" хэмээн тодорхойлсон байдаг. Сэбаллос-Ласкурэйн эко аялал жуулчлалыг анх 1996 онд тодорхойлсон бөгөөд тэрээр "Ургамал, ан амьтан, соёльн дурсгалт газруудын дүр төрхтэй танилцах, бишрэх, суралщах, мэтчилэн тодорхой зорилтын хүрээнд унаган төрхөө харьцангуй хадгалан үлдсэн, доройтол, бохирдолд бага өртсөн нутаг дэвсгэрт аялахыг эко-аялал жуулчлал гэнэ” хэмээжээ. Олон улсын эко аялал жуулчлалын нийгэмлэгээс (International Ecotourism Society) "Байгаль орчныг хамгаалах, орон нутгийн иргэдийн амьдральг сайжруулахад чиглэсэн байгальд хандсан аялал жуулчлалыг эко аялал жуулчлал гэнэ” хэмээсэн байна. 1985 онд Дэлхийн Аялал Жуулчлалын Байгууллага /WTO/, Нэгдсэн Үндэсний байгууллагын Байгаль Орчны Хөтөлбөр /UNEP/ “Аялал жуулчлал ба Байгаль орчны тухай хамтарсан тунхаглал”даа "Байгаль хамгаалахад аялал жуулчлальн уялдаа холбоог бэхжүүлснээр хөгжлийн үндсэн нөхиөл болно” гэж заажээ.

Японы Экотуризм нь 1988 онд халим ажиглах хэлбэрээр Огисавара аралд анх үүссэн гэж үздэг. Японд Халим Ажиглах Холбоо 1989 онд байгуулагдсан. 1991 онд Байгаль орчны агентлагаас Окинава аралд Экотуризмыг дэмжих арга хэмжээг 
хэрхэн хэрэгжүүлэх талаар судалгаа шинжилгээний ажил эхлүүлсэн. Энэ нь үндэсний хэмжээний анхдагч санаачлага байсан гэж хэлж болно. 1990-ээд оноос Экотуризм нь анхаарал татаж эхэлсэн. 1992 онд Япон Дэлхийн өвийн конвенцид нэгдэж, 1993 онд /白神山地/ Ширэками уулс, Якүшима арал /屋久島/-ыг Дэлхийн Байгалийн өвд бүртгүүлсэнээр Экотуризмын эхлэлийг тавьсан. ${ }^{11}$ Дэлхийн өвд бүртгэгдсэнээс хойш Якүшима, Ширэкамиг зорих жуулчдын тоо эрс нэмэгдсэн байна.

Үүнээс хойш аж ахуйн нэгжүүд орон даяар эко аяллыг хэрэгжүүлэх үйл ажиллагааг эхлүүлсэн. Ириомотэ арал /西表 島/, Якүшима арал/屋久島/, Карүйзава /軽井沢/, Ширэтоко / 知床/ гэх мэтчилэн. 1996 онд Ириомотэ Экоторузмын нийгэмлэг байгуулагдсан. 1998 онд Японы Экотуризмыг дэмжих зөвлөл (одоогийн Японы Экотуризмын Нийгэмлэг) байгуулагдсан. 1999 онд Якүшимад 'Eco guide' зөвлөл байгуулагдсан. 2004 онд Экотуризмыг дэмжих зөвлөл нь “Экотуризмыг дэмжих таван арга хэмжээг "-г боловсруулж, “13 бүс нутгийг хөгжүүлэх загвар төсөл”-ийг хэрэгжүүлж эхэлсэн. 2007 онд Экотуризмыг дэмжих тухай хууль батлагдаж, уг хууль хүчин төгөлдөржсөн. 2008 онд Засгийн газар “Экотуризмыг хөгжүүлэх үндсэн чиглэл”"2-ийг баталсан.

2004 оны зургадугаар сард тус хороо “Экотуризмыг хөгжүүлэх таван арга хэмюжээ"13 -г баталсан. Эдгээр таван арга хэмжээ нь :

1. Экотуризмын дүрэм. Экотуризмын ойлголтыг аж ахуйн нэгж, сайн дурынхан, аялагчид, нутгийн иргэдэд хялбар аргаар ойлгуулахын тулд экотуризмын дүрмийг боловсруулах.

2. Экотуризмын мэдээлэл. Эко аялагчдыг нэмэгдүүлэхийн тулд эко аяллын хөтөлбөрийн тухай мэдээлэлтэй вэб сайтуудыг танилцуулах, экотуризмын сэдэвт семинар, форум, уулзалтын талаарх мэдээллийг хурдан шуурхай олон нийтэд хүртээмжтэй түгээх.

11 Journal of Marine and Island Cultures Volume5.Issue1, June 2016 "Ecotourism and World Natural Heritage: Its influence on island in Japan"P-36

12 “Экотуризмыг хөгжүүлэх үндсэн чиглэл” 2008 оны 6 дугаар сарын 6-ны өдрийн Япон улсын Засгийн газрын тогтоол.『エコツーリズム推進基本方針』/平成20年 6月6日閣議決定/

13 Экотуризмыг хөгжүүлэх таван арга хэмжээ『エコツーリズム推進 5 つの方策』 
3. Экотуризмын шагнал. Эко аялал жуулчлалаар үйл ажиллагаа явуулж буй аж ахуйн нэгжүүдийг шалгаруулан шагнаж урамшуулах.

4. Экотуризмыг дэмжих гарын авлага. Эко аялал жуулчлалыг дэмжих гарын авлагыг эмхтгэх, эко аялал жуулчлалын үзэл санааг хэрэгжүүлэх, зорилтуудыг танилцуулах, зааварчилгаагаар хангах.

5. Экотуризмын загвар төсөл. Эко аяллыг хөгжүүлэхийн тулд Байгаль орчны яамнаас сонгосон 13 бүс нутагт 3 төрөлд хуваан өөр өөр төсөл хэрэгжүүлсэн. 1 дугаар төрөл. Байгалийн үзэсгэлэнт бүс нутаг (知床地区/Ширэтоко бүс, 白 神地区Шираками бүс, 小笠原地区/Огасавара бүс, 屋久島地 区/Якүшима бүс) 2 дугаар төрөл. Жуулчид олноор аялдаг бүс нутаг (裏磐梯地区/Үрабандай бүс, 富士山ほくろ駆逐/Хойд Фүжи, 六甲地区/Рокко бүс, 佐世保地区/Сасэбо бүс) 3 дугаар төрөл. 里地里山/Сатоши Сатояма шиг үйлдвэржилт өндөр хөгжсөн, соёлын түвшин өндөр бүс нутаг, (田尻地区/Тажири бүс, 飯田地区/Ийда бүс, 湖西地区/Косэй бүс, 南記熊野地 区/Нанки Кумано бүс) гэсэн 3 хэсэгт бүсчлэн аялал жуулчлал хөгжүүлэх бодлого явуулж иржээ.

Эдгээр төслийн гол үйл ажиллагаа 3 жилийн хугацаатай Экотуризмыг хэрэгжүүлэх загвар төслийг 2004 оноос эхэлж байжээ. БОЯ-аар сонгогдсон 13 бүс нутгийг 3 төрөлд хувааж, бүс нутаг бүрт өөр өөр төсөл хэрэгжүүлж иржээ. 1. Эко аялал жуулчлалыг дэмжих зөвлөл байгуулах. Энэ нь орон нутгийн засаг захиргаа, хөтөч, аяллын агентлаг, Төрийн Бус Байгууллагаас бүрдсэн. 2. Байгаль хамгаалалд зориулсан аяллын дүрэм боловсруулах 3. Хүний нөөцийг хөгжүүлэх болон Эко аялал жуулчлалыг хэрэгжүүлэх хөтөлбөрүүдийг боловсруулж, дагаж мөрдөж иржээ. Ингэхдээ 13 бүс нутаг загвар төслийн явцыг тайлагнах, хэлэлцэх, санал бодлоо солилцох, мөн цахим хуудсаар дамжуулан 13 загвар бүс нутгийн мэдээллийг дэлгэрэнгүй түгээх боломжийг хангаж, 3 жилийн төслийн явцад эко аялал жуулчлалыг дэмжих, эко аяллын суурийг бий болгох, дараагийн 3 жилд загвар төслийн үр нөлөөг улам дээшлүүлэх, хүчин чармайлтаа цаашид ч нэмэгдүүлж ажиллахад анхаарлаа чиглүүлж иржээ. Эдгээр арга хэмжээг хэрэгжүүлэхдээ: Түүх, соёлын өвийг 
хадгалсан байгалийн цогцолборт газруудыг зүй зохистой ашиглах; Нутгийн оршин суугчид болон аялагчдын байгаль орчны мэдлэгийг дээшлүүлэх; Жилд жуулчлах жуулчдын тоог нэмэгдүүлэх; Шинээр ажлын байр бий болгох боломжийг бүрдүүлэх зэрэгт анхаарч, ач холбогдол өгч ажилладаг байна.

\section{Хоёр. Байгалийн цогцолборт газрыг зүй зохистой ашиглахад чиглэсэн зарим төслуүд}

Японы хувьд экотуризм нь Дэлхийн байгалийн өвтэй салшгүй холбоотой, дэлхийн байгалийн өвд бүртгэгдсэнээр тус орон нутагт бүс нутгийн хөгжил, байгаль хамгаалах асуудлаар анхаарал тавин ажилладаг. 1993-2016 онд, Японы түүх соёлын дурсгалт өв болсон 19 газрыг дэлхийн өвийн санд бүртгүүлсэн байна. Японд Үндэсний цогцолборт газар 28 байдаг, энд жилд ойролцоогоор 370 сая хүн жуулчилдаг. Зарим нутагт хөрсний элэгдэл, хог хаягдал, замын түгжрэл зэрэг асуудлууд тулгамдах болсныг үндэслэн, байгалийн цогцолборт газруудад тогтвортой аялал жуулчлалыг дэмжих дараах төслүүдийг хэрэгжүүлэх бодлогыг дэвшүүлж иржээ. Үүнд, 1. Автомашины тоог зохицуулах. 2. Уулын аялал маршрут буюу уулын жимээр аялах, замуудыг хэвээр хадгалах, ойр орчмынх нь ургамлын нөхөн сэргээлтийг хийх. 3. Уулархаг нутагт бие засах газар барихад татаас авах. 4. Газар нутгийг зохицуулалттай ашиглах систем бий болгох арга хэмжээг авч хэрэгжүүлсэн байна.

Японы Үндэсний цогцолборт газруудын газар өмчлөл хувийн болон улсынхаас үл хамааран Байгаль орчны яам удирддаг, түүнчлэн БОЯ нь бусад яамд, орон нутгийн засаг захиргаа, хувийн хэвшилтэй хамтран ажиллаж зарчмыг мөрддөг байна.

\section{Гурав. Тогтвортой аялал жсуулчлалын гарын авлага}

БОЯ нь 1996 оноос IUCN (International Union Conservation National) -ийн Зүүн Азийн төсөлд хувь нэмрээ оруулж, Зүүн Азийн орнуудын тусгай хамгаалалттай болон байгалийн цогцолборт газруудад аялах гарын авлагыг мөрдөж иржээ. Уг гарын авлага Япон, Хятад, Солонгос улсыг багтааж, тухайн орны хэл дээр нийтлэгдэж 
иржээ.

Жуулчид ихээр цуглардаг байгалийн тусгай хамгаалалттай газрын менежрүүдэд туслах зорилготой, цогцолборт газруудын менежрүүд ажилдаа тусгавал зохих агуулгыг уг гарын авлагад тусган иржээ. Цогцолборт газрын менежерүүдийн соёлын болон байгалийн жуулчлалын хамтын ажиллагааг дэмжих, зохицуулахад энэ гарын авлага зохих ач холбогдолтой болжээ.

\section{Дүгнэлт}

Япон улс тогтвортой аялал жуулчлалын бодлогоо хэрэгжүүлэхдээ экотуризмыг хөгжүүлэх арга хэмжээг түлхүҮ авч иржээ.

Нэгт, хууль эрх зүйн хүрээнд. БОЯ нь 2003 оны 11 дүгээр сараас эхлэн “Экотуризмыг хөгжүүлэх зөвлөл”-ийн хурлыг 8 удаа зохион байгуулж, 2004 оны 6 дугаар сард “Экотуризмыг хөгжүүлэх таван арга хэмжээ"-г баталсан юм. 2007 онд буюу 10 жилийн өмнө Экотуризмыг хөгжүүлэх тухай хууль батлагдаж, уг хууль хүчин төгөлдөржсөн. Хууль эрх зүйн хүрээнд шийдэгдэтлээ 15 жилийн хугацааг туулахдаа хувийн хэвшлийн үйл ажиллагаанд тулгуурлан Екотуризм нь хөгжиж байсан юм.

Хоёрт, техник технологийн хүрээнд. Технологитой холбоотой асуудлуудад дараах зүйлүүд багтана. (1) ердийн тээврийн хэрэгслийг үндэсний цогцолборт газарт замын хөдөлгөөний хяналт тавьж, утаа бага ялгаруулдаг тээврийн хэрэгслээр орлуулах, (2) нарны системээр үйлдвэрлэсэн цахилгаан эрчим хүчээр хангах. Нарны эрчим хүч үйлдвэрлэлийг одоогоор зочид буудал, жуулчны бусад байгууллагууд ашиглаж байна.

Гуравт, Хүний нөөцийг хөгжүүлэх хүрээнд. Экотуризмын сэдэвт сургалт семинарыг орон даяар тогтмол зохион байгуулж, олон улсын болон бүс нутгийн хэмжээний чуулга уулзалтуудад холбогдох яамд байгууллага, сайн дурынхан, мэргэжилтнүүд идэвхитэй оролцох, эко аяллын мэдээ мэдээллийг олон нийтэд хүртээмжтэй, хурдан шуурхай интернэтээр дамжуулан түгээх, Эко аялагчдын холбоо, группүүд хамтран ажиллаж, санал бодол, туршлагаа хуваалцах, жил бүр Экотуризмын шагнал гардуулах үйл ажиллагаа одоог хүртэл 
тасралтгүй хэрэгжиж байна.

Эдгээр хүчин зүйлс нь ухамсарт буюу хариуцлагатай аялагчдыг бий болгож, эко аялагчдын тоог нэмэгдүүлэх, японы эко аяллын төрлүүдийг бий болгох, аялал жуулчлалыг улс орны хэмжээнд эдийн засгийн том хөшүүрэг болгох, аяллын бүс нутгийг хөгжүүлэх, аялал жуулчлалын салбарын хүний нөөцийг хөгжүүлэх, ард түмэн байгаль хамгаалах талаар гүнзгий мэдлэг олж авах гээд маш олон эерэг өөрчлөлтийг авчирч байна.

\section{Ном зүй:}

\section{Англи хэлээр}

1. Mongolia's sustainable development agenda: progresses, bottlenecks and vision for the future. UB. 2012.

2. Tourism 2020 Vision.Volume7 . web:www.world-tourism.org

3. World Travel \&Tourism Council. Travel \& Tourism, Economic Impact 2015 Japan.www.wttc.org

4. UNWTO Long term forecasts - Tourism towards 2030

5. World Economic Forum. The Travel \&Tourism Competitiveness Report 2015. Web:www.weforum.org

6. Best Practices of Sustainable Tourism in JAPAN Submitted to the Ministerial Consultations of the 9th Special Session of the Governing Council / Global Ministerial Environment Forum.

7. APEC Ecotourism Conference Sendai, Japan16 September 2010“ Ecotourism promotion policy in Japan" Ecotourism promotion Act.No 105 of June 27.2007.

8. Tourism Nation Promotion Basic Plan.approved by the Cabinet on march 30.2012 .

9. United Nations Conference on Environment \& Development Rio De Janerio Brazil. 3-14 June 1992. Agenda21.

10. "Japan, Mongolia and the potential of Ecotourism" Micheal Sutton.

11. OECD Tourism Trends and policies. 2016

12. Overview of Japan's Sustainable Tourism Development. Japan Association of Travel Agents April 27.2013 
13. Selected Japanese Environmental technologies for Green industry.

14. Natural Park System in Japan. Ministry of the Environment, Japan

15. Tourism planning and Development

16. "Ecotourism and World Natural Heritage: Its influence on island in Japan" Journal of Marine and Island Cultures. Volume5. Issue1, June., 2016. P-36-46

17. "Seven-year Program for Coastal Protection and Management" United Nations Conference on Environment \& Development Rio De Janerio Brazil. 3-14 June 1992. Agenda21.

Япон хэлээр

1. Байгаль орчны суурь төлөвлөгөө. 2000 он 12 дугаар сар 『環境 基本計画』平成 12 年 12 月

2. Япон улсын Биологийн олон янз байдлын стратеги төлөвлөгөө 2012-2020 『生物多様性国家前略2012-2020の 構成』

3. Ой болон ойн аж ахуйн суурь төлөвлөгөө.2016 оны 5 дугаар cap 『森林・林業基本計画』平成 28 年 5 月

4. “Аялал жуулчлалын цагаан ном” 2015 он.Аялал жуулчлалын агентлаг. №52.

5.『観光白書』平成 27 年版、『観光立国推基本進 法』"Үндэсний аялал жуулчлалыг хөгжүүлэх суурь хууль"

6. "Үндэсний аялал жуулчлалыг хөгжүүлэх суурь төлөвлөгөө" 『観光立国推進基本計画』

7. “Экотуризмыг хөгжүүлэх тухай хууль” 2007.06.27. 105-р заалт『エコッーリズム推進法』/平成十九年六月二十七日法 律第百五号/

8. “Экотуризмыг хөгжүүлэх үндсэн чиглэл” 2008 оны 6 дугаар сарын 6-ны өдрийн Япон улсын Засгийн газрын тогтоол 『エ コッーリズム推進基本方針』/平成20年6月6日閣議決定/

9. (Япон дахь Экотуризмын үйл ажиллагааны тайлан)『日本に おけるエコッーリズムの取組について』 


\section{SUSTAINABLE TOURISM POLICY OF JAPAN AND ECO-TOURISM EXPERIENCE}

\section{B.Saranchimeg}

The general trend of global development of current time are to transfer into 'green' style of development through to engrain proper usage, to develop eco-friendly industry, and to keep own characteristic or wealth of nationals. In that case, we are facing negative and positive impacts while rapidly developing the one of core sector of national economy. The way of to increase positive and decrease negative impacts of tourism industry is to seek principals for sustainable tourism development. The environment, national culture and tradition or value, which helps to distinguishing nation from others, are most affected and lost its own characters by tourism activities. Preserve those values for their nest generation is becoming common policy, goal as well as objective of all countries of the world. The Japan is best example for introducing 'green development' form in all economic sectors as well as tourism. In Mongolia, we should learn Japanese experience while implement following short description 'Tomorrow's tourist must have opportunities to feel and to see same as today's tourist".

Keywords: Green development, sustainable development, sustainable tourism, eco-tourism 